\title{
ANALYSIS OF ACUTE AND EARLY PERIODS COMPLICATIONS OF TRAUMATIC DISEASE IN SEVERE POLYTRAUMA
}

\author{
Matvieienko M., Baranova N., Kozlova T., Matvieienko S., Gryshchenko A., Sukesh Arora
}

Objective of the research is to assess the likelihood of complications in the acute and early periods of Traumatic Disease (TD) and primary condition and reserve capability of hemodynamic and homeostasis in patients with polytrauma.

Materials and methods. A retrospective study was carried out on 32 patients suffering from polytrauma. The group of the study included patients with the severity of injury according to the Injury Severity Score (ISS) more than 25 points and on a scale APACHE II 10-25 points at the time of admission. The estimated blood loss was 30-40\% of blood volume (BV). The individual assessment of blood loss was calculated by Moor.

Results. The study of $20(62.5 \%)$ men, $12(37.5 \%)$ women aged 18 to 60 years old (35.22 \pm 12.66$)$ were done. The mechanical ventilation was performed for 30 patients $(93.75 \%)$, and 2 patients $(6.25 \%)$ required oxygen therapy 5 lit per min for 3 days. The duration of mechanical ventilation was in 10 patients - up to 1 day, 8 patients - up to 3 days and at 12 - more than 3 days. Among 12 patients, who used AMV (artifitional mechanical ventilation) more than 3 days, 10 patients were tracheostomy in $3 \mathrm{~d}$ day and 2 patients were extubated on 4th day. Among the patients examined thirty patients $(93.7 \%)$ had posthemorrhagic anemia during first day of injury. Infectious complications like purulent tracheobronchitis and pneumonia were observed in $14(43.75 \%)$ patients. The local infectious complications (abscesses, festering wounds) occurred in $5(15.6 \%)$ patients and bedsores in $3(9.375 \%)$ patients. The catheterization of the bladder lead to the development of urinary tract infection in 3 patients $(9.3 \%)$.

Conclusion. The most problematic category of victims includes patients with injuries several anatomical regions. Pneumonia, anemia, urinary tract infection and local infectious complications were considered as the most common complications of acute and early periods TD. The factors that influenced the probability of a high degree of complications were AMV, the thoracic component of the injury, more massive blood loss, long-term catheterization of the bladder.

KEY WORDS: polytrauma, traumatic disease, complications, acute period, early period

\section{INFORMATION ABOUT AUTHOR}

Matvieienko Mariia S., MD, Assistant, Department of of Surgical Diseases, Operative Surgery and Topographical Anatomy, V. N. Karazin Kharkiv National University, School of Medicine, 6, Svobody Sq.,Kharkiv, Ukraine, 61022, e-mail: mariia.matvieienko@karazin.ua, ORCID ID: http://orcid.org/0000-0002-0388-138X

Baranova Nadegda V., MD, PhD, Assistant, Department of Emergency medicine, Anesthesiology and Intensive Care, Kharkiv National Medical University, 4, Nauky Avenue, Kharkiv, Ukraine, 61022,

e-mail: nadezhdav.baranova@gmail.com

Matvieienko Serhei V., MD, Anesthesiologist of the Intensive Care Unit for patients with multiple trauma, KNP «Kharkiv City Clinical Hospital of Emergency», 3 a, Balakireva Street, Kharkov, Ukraine, 61000,

e-mail: doctor.lector05@gmail.com

Kozlova Tetiana V., MD, PhD, Associated professor, Department of General and Clinical Pathology, V. N. Karazin Kharkiv National University, School of Medicine, 6, Svobody Sq., Kharkiv, Ukraine, 61022, e-mail: takovl@ukr.net Gryshchenko Alona, MD, Assistant, Department of Surgical Diseases, Operative Surgery and Topographical Anatomy., V. N. Karazin Kharkiv National University, School of Medicine, 6, Svobody Sq., Kharkiv, Ukraine, 61022, e-mail: grishenko@karazin.ua

Sukesh Arora, MD, Assistant, Department of Surgical Diseases, Operative Surgery and Topographical Anatomy, V. N. Karazin Kharkiv National University, School of Medicine, 6, Svobody Sq., Kharkiv, Ukraine, 61022, e-mail: asukesh35@gmail.com

\section{INTRODUCTION}

On the average, $80-85 \%$ of all deaths in Ukraine can be divided into three main classes of causes of death: cardiovascular diseases, cancer and caraccidents, poisoning and injuries (impact of external factors) $[1,2]$.

The leading causes of combined trauma are road traffic accidents (38-65\%), falling from a height (24-32\%) and others (8-14\%) [3, 4]. 
According to data of the World Health Organization, Ukraine is one of the top 10 European countries with the highest mortality rate as a result of an accident, and 10 people out of 100 thousand people are the victims of traffic accident in Ukraine annually [5].

One of the main components why Ukraine falls behind developed countries is high level of mortality from external causes. The losses Ukraine suffers due to these causes of death are notlower, and in the age groups up to 70 years old - are much higher than the losses from oncological diseases. As for men under the age of 45 at risk of traumatic injuries more than cardiovascular diseases [6]. Considering the traffic safety data a steady mortality rate is known to have increased from 2014 to 2017.

In accordance with various authors, the total mortality of traumatized in Intensive Care Units (ICU) ranges from 5.5 to $10 \%$, while among patients with lesions in three anatomical sites, the mortality rate is $10-20 \%$. The highest hospital mortality is observed in victims with competing dominant injuries $-60 \%[7,8]$.

The structure of deaths from trauma accounts for $66 \%$ of pre-hospital period. Also, a fairly high mortality rate is characteristic for the first 48 hours [9]. The main causes of early lethality in polytrauma are acute blood loss and shock $(13.5 \%)$ due to damage of the parenchymal organs of the abdominal cavity, kidneys, great vessels of chest, fractures with displacements of the anterior and posterior semicircles of the pelvis. «Brain death» occurs more often from edema and dislocation of the brain in victims with Trauma Brain Injury (TBI) $(17.9 \%)$ in the period from 1 to 3 days. Infection complications (pneumonia, purulent intoxications, sepsis) (28.9\%), and Multiple Organ Dysfunction (MODS)-37\% are more typical for the period till 4 days after trauma[10].

The maintenance of homeostasis in case of severe trauma is based on universal mechanisms, united by the concept of immune distress syndrome. The key links that trigger this reaction are: hypoxia caused by a violation of oxygen delivery to the tissues and an increase in their energy consumption; tissues damages. The most expressed metabolic changes occur on the 5-7-th days and are manifested by organ failure or MODS. Exactly the acute period of traumatic disease (TD) becoming crucial for the formation of the immune response. At the stage of early manifestations TD, the causes of SIRS initiation followed by the formation of Multiple Dysfunction Syndrome is endogenous intoxication [11].

\section{OBJECTIVE}

Objective of the research is to assess the likelihood of complications in the acute and early periods of Traumatic Disease and primary condition and reserve capability of hemodynamic and homeostasis in patients with polytrauma.

\section{MATERIALS AND METHODS}

A retrospective study was carried out on 32 patients suffering from polytrauma, who were treated at the anesthesiology and intensive care unit (AICU) for patients with combined trauma in the Kharkiv City Clinical Hospital of Emergency Medicine in the period from 2015 to 2016.

All victims were divided into the groups considering body injured regions: head, chest, abdomen, and skeletal trauma. The group of the study included patients with the severity of injury according to the Injury Severity Score (ISS) more than 25 points and on a scale APACHE II 10-25 points at the time of admission. The patients with severe TBI - Glasgow Coma Scale $(\mathrm{GCS} \leq 13)$ were excluded from the study group. The estimated blood loss was $30-40 \%$ of blood volume (BV). The individual assessment of blood loss was calculated by Moor [12]. The standard indicators of clinical and biochemical analyzes were evaluated. In addition, was estimated number and type of complications. Also, the incidence of purulent tracheobronchitis and pneumonia were analyzed depending on the severity of injury and using of artificial mechanical ventilation (AMV).

All patients received traditional intensive care according to the local clinical protocol of Polytrauma management (Dnipro, in 2016 a review by prof. H. Klyhunenko). Depending on the severity of the injuries and condition they were administered infusion-transfusion, analgesic, anti-inflammatory, antibacterial and metabolic drugs, was provided prevention of gastrointestinal ulcers.

All the data were processed by methods of mathematical statistics and presented as: mean \pm standard deviation.

\section{RESULTS}

The study of $20(62.5 \%)$ men, $12(37.5 \%)$ women aged 18 to 60 years old $(35.22 \pm 12.66)$ were done. The causes of polytrauma were car accidents - in $20(62.5 \%)$ patients, falling from the height $-8(25 \%)$ and domestic trauma $-4(12.5 \%)$. 
The most of the patients arrived at the hospital rather quickly. $23(71.8 \%)$ patients were delivered to hospital for 1 hours from the time of injuries, $6(18.7 \%)$ - for 2 hours, and 3(9.3\%) - late than 2 hours.

The structure of Multiply injuries included:

-13 patients with closed chest injury and skeletal trauma,

- 2 patients with closed abdominal trauma and pelvis trauma,

-5 patients with closed abdominal and skeletal trauma,

- 1 patient with closed chest injury, closed abdominal trauma and pelvis trauma,
- 4 patients with closed chest injury, pelvis trauma, and skeletal trauma,

-2 patients with closed abdominal injury, pelvis trauma and skeletal trauma.

The severity of injuries graded by the ISS scale was $26.84 \pm 4$.1. The level of consciousness by the GCS was $13.5 \pm 0.5$ points. In assessing the severity scale for patients with APACHE II was $14.97 \pm 2.78$ points. The degree of blood loss in the surveyed group corresponded to the III class according to the classification of the American college of surgeons and amounted to $35.21 \pm 4.52 \%$ of the BV (tab. 1).

The characteristics of the victims

\begin{tabular}{|c|c|}
\hline Investigated index & Retrospective group \\
\hline The total number of patients & $(\mathrm{n}=32)$ \\
\hline Gender composition & $20(62,5 \%)$ \\
Male & $12(37,5 \%)$ \\
\hline Female & $35,22 \pm 12,66$ \\
\hline Middle age, years & $73,84 \pm 11,86$ \\
\hline Body weight, kg & $26,84 \pm 4,1$ \\
\hline ISS, point & $13,5 \pm 0,5$ \\
\hline GCS, point & $14,97 \pm 2,78$ \\
\hline APACHE-II, point & $35,21 \pm 4,52$ \\
\hline Blood loss, $\%$ & \\
\hline
\end{tabular}

Most of the patients required support of the respiratory function (tab. 2). The mechanical ventilation was performed for 30 patients $(93.75 \%)$, and 2 patients $(6.25 \%)$ required oxygen therapy 5 lit per min for 3 days. The duration of mechanical ventilation was in 10 patients - up to 1 day, 8 patients - up to 3 days and at 12 - more than 3 days. Among 12 patients, who used AMV more than 3 days, 10 patients were tracheostomy in $3 d$ day and 2 patients were extubated on 4 th day.

Distribution of the patients depending on the type of respiratory support

Table 2.

\begin{tabular}{|c|c|c|c|c|c|c|c|}
\hline $\begin{array}{c}\text { The type of } \\
\text { respiratory } \\
\text { support }\end{array}$ & Duration & $\begin{array}{c}\Xi \\
\dot{\bar{\Xi}} \\
\hat{\Xi} \\
\bar{Z}\end{array}$ & 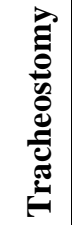 & ISS, point & GCS, point & $\begin{array}{c}\text { APACHE } \\
\text { II, point }\end{array}$ & $\begin{array}{c}\text { Amount of } \\
\text { blood loss, } \mathrm{ml}\end{array}$ \\
\hline $\begin{array}{c}\text { Oxygen therapy } \\
\text { without AMV }\end{array}$ & up to 3 days & 2 & 0 & $22 \pm 0$ & $14 \pm 0$ & $11,5 \pm 0,7$ & $2229 \pm 24$ \\
\hline \multirow{3}{*}{ AMV } & within 1 day & 10 & 0 & $24 \pm 1,94$ & $13,9 \pm 0,3$ & $13,5 \pm 2,83$ & $2351,7 \pm 147,52$ \\
\hline & up to 3 days & 8 & 0 & $25,75 \pm 2,49$ & $13,38 \pm 0,52$ & $15,25 \pm 2,12$ & $2237 \pm 162,15$ \\
\hline & $\begin{array}{c}\text { more than } 3 \\
\text { days }\end{array}$ & 12 & 10 & $30,75 \pm 3,36$ & $13,16 \pm 0,34$ & $16,58 \pm 2,27$ & $2912 \pm 88$ \\
\hline
\end{tabular}

Pneumonia, anemia, urinary tract infection and local infectious complications were considered as the most common complications of acute and early periods of TD.
Among the patients examined thirty patients $(93.7 \%)$ had posthemorrhagic anemia during first day of injury. On the 3rd day the number of patients with anemia slightly decreased to 25 
(78.1\%). On the 5th day - it became for $13(50 \%)$, and by the end of the early period TD it decreased to $3(9.3 \%)$ people. Anemia was occured in the case of hemoglobin decrease less than $100 \mathrm{~g} / \mathrm{l}$, which affected on postponed orthopedic correction schedule.

Infectious complications like purulent tracheobronchitis and pneumonia were observed in $14(43.75 \%)$ patients. The factor that influenced the probability of a high degree of complications was AMV. All of the patients with pneumonia and purulent tracheobronchitis were performed AMV for 3 days or more, which was due to the presence of the thoracic component of the injury and more massive blood loss $(2770 \pm 354 \mathrm{ml})$. Unlike the patients who did not have infectious pulmonary complications and had ISS of $23.94 \pm 2.04$ points, the middle score by the ISS scale for the group with complications was $30.35 \pm 3.27$ points. The severity of the patients with complications according to APACHE II scale was $16.93 \pm 1.98$ points, in contrast to the patients without these complications $-13.4 \pm 2.4$ points.

The local infectious complications (abscesses, festering wounds) occurred in $5(15.6 \%)$ patients and bedsores in $3(9.375 \%)$ patients. The catheterization of the bladder lead to the development of urinary tract infection in 3 patients $(9.3 \%)$. Patients in this group were characterized by long-term catheterization of the bladder (longer than 3 days) associated with the damage of the pelvic bones with rotational and vertical instability and the complete rupture of the pelvic ring. 4 patients had no complications, one complication was observed in $59.3 \%$ (19 patients), two - in $18.7 \%$ (6 patients), and three - in $9.3 \%$ (3 patients).

\section{DISCUSSION}

The most problematic category of victims includes patients with injuries several anatomical regions. On the one hand, each site requires the correction of its anatomical integrity. On the other hand, these lesions lead to severe physiological changes and almost depletion of the physiological reserve. It can prevent the definitive surgical recovery of all injuries simultaneously. According to the principles of «damage control» balance between anatomical and physiological restoration always occurs.

This study describes the clinical characteristics and outcomes for patients admitted to the AICU for patients with combined trauma in the Kharkiv City Clinical Hospital of Emergency Medicine after traumatic injury. We found that hospital complications developed in more than half of the cases and associated with a higher severity of injury (ISS $26.84 \pm 4.1$ ) and more massive blood loss $(2770 \pm 354 \mathrm{ml})$. It was established that the most common complications of acute hospital period of TD with combined trauma were pneumonia $(43.75 \%)$, anemia $(93.75 \%)$, urinary tract infection $(15.6 \%)$ and local infectious complications $(9.375 \%)$. This is similar to the experience of Pankov I.O. [13].

Meghan Prin and Guo Hua Li described lower level of complications such as pneumonia and urinary tract infections in trauma patients treated in intensive care units in the United States, 2013 [14]. However, the data of Khubutia and Shabanov demonstrate a significantly higher level of pulmonary complications [15]. In our study the level of posthemorrhagic anemia and local infectious complications is comparable to the data of Perm State Medical University [16] and Ong AW [17].

The factors that influenced the likelihood of a high degree of complications can be considered - severe primary injuries, severe massive blood loss, long period of AMV.

The main task of resuscitation and intensive care in treating TD should be the restore vital functions of the body so they can be ready to performing urgent and postponed surgeries. The actual factor nowadays is searching for the ways to improve Intensive Care. That will reduce the number of complications and optimize the order of surgery correction

\section{CONCLUSION}

The most common complications of acute and early periods of TD with combined trauma were pneumonia, anemia, urinary tract infection and local infectious complications.

The severe primary injuries, severe massive blood loss, long period of AMV can be considered The factors that influenced the likelihood of a high degree of complications.

The main task of resuscitation and intensive care in treating TD should be the restore vital functions of the body so they can be ready to performing urgent and postponed surgeries. The actual factor nowadays is searching for the ways to improve Intensive Care. That will reduce the number of complications and optimize the order of surgery correction. 


\title{
REFERENCES
}

1. Kovalenko, V. M., Dorogoi, A. P., Sirenko, Yu. M. (2013). Diseases of the circulatory system in the mortality structure of the population of Ukraine: myths and reality. Materials of the IV National Congress of Cardiologists of Ukraine, 22-29 [in Ukraine].

2. Medvedovska, Yu. V. (2013). Modern studies of tumors and factors contributing to its growth. Family medicine, № 5, 30-34 [in Ukraine].

3. Blazhenko, A. N., Zavrazhnov, A. A., Dubrov, V. E., Blazhenko, A. A. (2011). Assessment of informativeness of diagnostic methods for combined and multiple injuries in the acute period of polytrauma in a multidisciplinary hospital. Emergency Medical Aid, 12 (№ 4), 68-75 [in Russian].

4. Skinner, D., Driscoll, P. (2013). ABC of Major Trauma. BMJ Publishing Group - 4th edition.238.

5. WHO Library Cataloguing-in-Publication Data World health statistics 2018: monitoring health for the SDGs, sustainable development goals. 2018. 34.

6. Chepelevska, L. A., Rudnitski, O. P., Dziuba, O. M. (2014). Problems of the Demographic Crisis in Ukraine: A Regional Aspect. Ukraine. The health of the nation, № 4(32), 5-9 [in Russian].

7. Linchevskiy, O. V., Miasnikov, D. V., Makarov, A. V., Hetman, V. H. (2012). Combined trauma: to survive until dawn (problem article). Trauma, 13 (№ 2), 98-102 [in Ukraine].

8. Nirula, R. (2010 Sep.). Scoop and run to the trauma center or stay and play at the local hospital: hospital transfer's effect on mortality. Trauma. 69(3), 595-599.

9. Bakke, H. K., Dehli, T., Wisborg, T. (2014). Fatal injury caused by low-energy trauma - a 10-year rural cohort. Acta Anaesthesiologica Scandinavica, № 58 (6), 726-732.

10. Agadzhanyan, V. V., Kravtsov, S. A., Shatalin, A. V., Levchenko, T. V. (2015). Hospital mortality in polytrauma and main directions for its decrease. Polytrauma, № 1, 6-15 [in Russian].

11. Kalinkin, O. G. (2013). Traumatic disease. Trauma, № 14, 59-65 [in Russian].

12. Lozhkin, A. V. (2004). Methods for estimating the volume and degree of blood loss. Bulletin of the blood service of Russia, № 4, 39-48 [in Russian].

13. Pankov, I. O. (2015). Analysis main mortality causes of the patients with severe skeletal polytrauma. Practical medicine, № 4-1(89), 157-160.

14. Prin, M., Li, G. (2016). Complications and in-hospital mortality in trauma patients treated in intensive care units in the United States, 2013. Injury Epidemiology, Vol. 3, 18, 1-10.

15. Khubutia, M. Sh., Shabanov, A. K., Chernenkaya, T. V., Godkov, M. A., Dorfman, A. G. (2011). Infectious Pulmonary Complications in Resuscitation and Intensive Therapy in Victims with Concomitant Injury. General resuscitation, № VII, 4, 24-27 [in Russian].

16. Schekolova, N. B., Ladeischikov, V. M., Zubareva, N. S. (2016). Early complications of Traumatic Disease with multiple injuries. Perm Medical Journal, XXXIII № 3, 25-30 [in Russian].

17. Ong, A. W., Omert, L. A., Vido, D., Goodman, B.M., Protetch, J., Rodriguez, A., Jeremitsky, E. (2009). Characteristics and outcomes of trauma patients with ICU lengths of stay 30 days and greater: a sevenyear retrospective study. Crit Care, № 13, R154. doi:10.1186/cc8054

\section{АНАЛІЗ УСКЛАДНЕНЬ ГОСТРОГО ТА РАННЬОГО ПЕРІОДУ ТРАВМАТИЧНОЇ ХВОРОБИ ПРИ ПОЛІТРАВМІ}

\author{
Матвєєнко М. С., Баранова Н. В., Козлова Т. В., Матвєєнко С. В., Грищенко А. В., Сукеш Арора
}

Метою даного дослідження $є$ оцінка ймовірності ускладнень в гострому і ранньому періодах травматичної хвороби (ТБ) і первинного стану, а також резервних можливостей гемодинаміки i гомеостазу у пацієнтів з політравмою.

Матеріали та методи. Ретроспективне дослідження було проведено на 32 пацієнтах, що страждають політравмою. До групи дослідження увійшли пацієнти 3 тяжкістю травми згідно шкали Injury Severity Score (ISS) більше 25 балів і за шкалою АРАCHE II на 10-25 балів на момент надходження. Передбачувана крововтрата становила 30-40\% об'єму циркулюючої крові (ОЦК). Оцінювали стандартні показники клінічних та біохімічних аналізів. Аналізували частоту розвитку ускладнень.

Результати. Було проведено дослідження 20 (62,5 \%) чоловіків, 12 (37,5 \%) жінок у віці від 18 до 60 років $(35,22 \pm 12,66)$. Механічна вентиляція була виконана 30 пацієнтам $(93,75 \%)$, а 2 пацієнтам (6,25 \%) потрібна була киснева терапія 5 л / хв протягом 3 днів. Тривалість штучної вентиляції легенів склала у 10 пацієнтів - до 1 дня, у 8 пацієнтів - до 3 днів і у 12 - понад 3 дні. Серед 12 пацієнтів, які використовували ШВЛ більше 3 днів, 10 пацієнтів були трахеостомовані на 3-й день і 2 пацієнти були екстубовані на 4-й день. Серед обстежених пацієнтів 30 (93,7\%) мали постгеморагічну анемію 
протягом першого дня травми. Інфекційні ускладнення, такі як гнійний трахеобронхіт і пневмонія, спостерігалися у 14 (43,75 \%) пацієнтів. Місцеві інфекційні ускладнення (абсцеси, гнійні рани) мали місце у 5 (15,6\%) пацієнтів і пролежні у 3 (9.375\%) пацієнтів. Катетеризація сечового міхура ускладнилася розвитком інфекції сечовивідних шляхів у 3 пацієнтів (9.3\%).

Висновок. Найбільш проблемна категорія постраждалих включає пацієнтів 3 травмами кількох анатомічних областей. Пневмонія, анемія, інфекція сечовивідних шляхів і місцеві інфекційні ускладнення вважалися найбільш поширеними ускладненнями гострого та раннього періодів ТБ. Факторами, що вплинули на ймовірність високого ступеня ускладнень, були ШВЛ, наявність торакального компонента травми, більш масивна крововтрата, тривала катетеризація сечового міхура.

КЛЮЧОВІ СЛОВА: політравма, травматична хвороба, ускладнення, гострий період, ранній період

\section{ИНФОРМАЦІЯ ПРО АВТОРІВ}

Матвєснко Марія Сергіївна, асистент кафедри хірургічних хвороб, оперативної хірургії та топографічної анатомії Харківського національного університету імені В. Н. Каразіна, майдан Свободи, 6, Харків, Україна, 61022, e-mail: mariia.matvieienko@karazin.ua, ID ORCID: http://orcid.org/0000-0002-0388-138X

Баранова Надія Вікторівна, к.мед.н., асистент кафедри медицини невідкладних станів, анестезіології та інтенсивної терапії Харківського національного медичного університету, проспект Науки, 4, Харків, Україна, 61022, e-mail: nadezhdav.baranova@gmail.com

Матвєєнко Сергій Віталійович, лікар-анестезіолог відділення анестезіології та інтенсивної терапії на 12 ліжок хворих зі сполученою травмою КНП «Харківська міська лікарня швидкої та невідкладної медичної допомоги», Балакирева, 3 а, м. Харків, Україна, 61000, e-mail: doctor.lector05@gmail.com

Козлова Тетяна Владиславівна, к.мед.н., доцент кафедри загальної та клінічної патології Харківського національного університету імені В.Н. Каразіна, майдан Свободи, 6, Харків, Україна, 61022, e-mail: takovl@ukr.net, ID ORCID: https://orcid.org/0000-0003-0432-6967

Гріщенко Альона Вікторівна, асистент кафедри хірургічних хвороб, оперативної хірургії та топографічної анатомії Харківського національного університету імені В. Н. Каразіна, майдан Свободи, 6, Харків, Україна, 61022, e-mail: grishenko@karazin.ua

Сукеш Арора, асистент кафедри хірургічних хвороб, оперативної хірургії та топографічної анатомії Харківського національного університету імені В.Н. Каразіна, майдан Свободи, 6, Харків, Україна, 61022, e-mail: asukesh35@gmail.com

\section{АНАЛИЗ ОСЛОЖНЕНИЙ ОСТРОГО И РАННЕГО ПЕРИОДОВ ТРАВМАТИЧЕСКОЙ БОЛЕЗНИ ПРИ ПОЛИТРАВМЕ}

\section{Матвеенко М. С., Баранова Н. В., Козлова Т. В., Матвеенко С. В., Грищенко А. В., Сукеш Арора}

Целью данного исследования является оценка вероятности осложнений в остром и раннем периодах травматической болезни (ТБ) и первичного состояния, а также резервных возможностей гемодинамики и гомеостаза у пациентов с политравмой.

Материалы и методы. Ретроспективное исследование было проведено на 32 пациентах, страдающих политравмой. В группу исследования вошли пациенты с тяжестью травмы согласно шкале Injury Severity Score (ISS) более 25 баллов и по шкале APACHE II на 10-25 баллов на момент поступления. Предполагаемая кровопотеря составляла 30-40 \% объема циркулирующей крови (ОЦК). Оценивали стандартные показатели клинических и биохимических анализов. Анализировали частоту развития осложнений.

Результаты. Было проведено исследование 20 (62,5 \%) мужчин, 12 (37,5\%) женщин в возрасте от 18 до 60 лет (35,22 + 12,66). Механическая вентиляция была выполнена 30 пациентам (93,75 \%), а 2 пациентам (6,25\%) потребовалась кислородотерапия 5 л/мин в течение 3 дней. Длительность искусственной вентиляции легких составила у 10 пациентов - до 1 дня, у 8 пациентов - до 3 дней и у 12 - более 3 дней. Среди 12 пациентов, которые использовали ИВЛ более 3 дней, 10 пациентов были трахеостомированы на 3-й день и 2 пациента были экстубированы на 4-й день. Среди обследованных пациентов $30(93,7 \%)$ имели постгеморрагическую анемию в течение первого дня травмы. Инфекционные осложнения, такие как гнойный трахеобронхит и пневмония, наблюдались у 14 $(43,75 \%)$ пациентов. Местные инфекционные осложнения (абсцессы, гнойные раны) имели место у 5 $(15,6$ \%) пациентов и пролежни у 3 (9,375 \%) пациентов. Катетеризация мочевого пузыря осложнилась развитием инфекции мочевыводящих путей у 3 пациентов $(9,3 \%)$.

Заключение. Наиболее проблемная категория пострадавших включает пациентов с травмами нескольких анатомических областей. Пневмония, анемия, инфекция мочевыводящих путей и местные инфекционные осложнения считались наиболее распространенными осложнениями острого и раннего 
периодов ТБ. Факторами, повлиявшими на вероятность высокой степени осложнений, были ИВЛ, наличие торакального компонента травмы, более массивная кровопотеря, длительная катетеризация мочевого пузыря.

КЛЮЧЕВЫЕ СЛОВА: политравма, травматическая болезнь, осложнения, острый период, ранний период

\section{ИНФОРМАЦИЯ ОБ АВТОРАХ}

Матвеенко Мария Сергеевна, ассистент кафедры хирургических болезней, оперативной хирургии и топографической анатомии ХНУ имени В. Н. Каразина, площадь Свободы, 6, Харьков, Украина, 61022, e-mail: mariia.matvieienko@karazin.ua, ID ORCID: http://orcid.org/0000-0002-0388-138X

Баранова Надежда Викторовна, к.мед.н., ассистент кафедры медицины неотложных состояний, анестезиологии и интенсивной терапии Харьковского национального медицинского университета, проспект Науки, 4, Харьков, Украина, 61022, e-mail: nadezhdav.baranova@gmail.com

Козлова Татьяна Владиславовна, к.мед.н., доцент кафедры общей и клинической патологии Харьковского национального университета имени В.Н. Каразина, площадь Свободы, 6, Харьков, Украина, 61022 , e-mail:takovl@ukr.net, ID ORCID: https://orcid.org/0000-0003-0432-6967

Матвеенко Сергей Витальевич, врач-анестезиолог отделения анестезиологии и интенсивной терапии на 12 коек больных с сочетанной травмой. КНП «Харьковская городская больница скорой неотложной медицинской помощи», пер. Балакирева, 3 a, Харьков, Украина, 61000, e-mail: doctor.lector05@ gmail.com

Грищенко Алена Викторовна, ассистент кафедры хирургических болезней, оперативной хирургии и топографической анатомии ХНУ имени В. Н. Каразина, площадь Свободы, 6, Харьков, Украина,61022, e-mail: grishenko@karazin.ua

Арора Сукеш, ассистент кафедры хирургических болезней, оперативной хирургии и топографической анатомии ХНУ имени В. Н. Каразина, площадь Свободы, 6, Харьков, Украина,61022, e-mail: asukesh35@gmail.com 